\title{
Synthesis and Characterization of Sustainable Man-Made Low Cost Clay Bricks with Bamboo Leaf Ash
}

\author{
Pius Rodney Fernando*, Gayan Lakpriya Kannangara, Gamage Prasad Buddhika, \\ Asmathul Urushiya
}

Department of Physics, Faculty of Science, Eastern University, Batticaloa, Sri Lanka

Email address:

Piusrf $a$ gmail.com (P. R. Fernando)

*Corresponding author

\section{To cite this article:}

Pius Rodney Fernando, Gayan Lakpriya Kannangara, Gamage Prasad Buddhika, Asmathul Urushiya. Synthesis and Characterization of Sustainable Man-Made Low Cost Clay Bricks with Bamboo Leaf Ash. Engineering Physics. Vol. 2, No. 1, 2018, pp. 15-22. doi: $10.11648 /$ j.ep.20180201.14

Received: March 15, 2018; Accepted: March 30, 2018; Published: May 9, 2018

\begin{abstract}
This studies investigated a few engineering properties of the effect of bamboo leaf ash blended with brick clay. The bamboo leaves used for this study have been gathered in the agricultural farm, Eastern University, Sri Lanka and the brick clay was acquired from Verpavettuvan, on the depth of 1 to $1.5 \mathrm{~m}$ beneath the earth surface. The leaves have been cleaned, sun-dried, burnt in an open environment and then bamboo leaf ash (BLA) has been obtained by heating in a muffle furnace at $600^{\circ} \mathrm{C}$ for 2 hours. Physical and chemical properties of BLA blended brick has been performed according to British and Indonesian Standard Specifications BS and SNI respectively. The chemical test showed that the total combination of Silica Oxide $\left(\mathrm{SiO}_{2}\right)$, Aluminum oxide $\left(\mathrm{Al}_{2} \mathrm{O}_{3}\right)$ and Ferrous oxide $\left(\mathrm{Fe}_{2} \mathrm{O}_{3}\right)$ content in BLA became above $70 \%$ minimal fashionable requirement targeted with the aid of ASTM (ASTM C 618, 2008) for pozzolanic substances. Sex type of BLA blended clay bricks have been manufactured at $0 \%, 2 \%, 4 \%, 6 \%, 8 \%$ and $10 \%$. A complete of 72 bricks comprising of 7 bricks for each percentage of the clay bricks of size $185 \mathrm{~mm}$ x $85 \mathrm{~mm}$ x $65 \mathrm{~mm}$. Those bricks have been cast with the addition of water-clay ratio of 0.6 to 0.8 to structure a very good workability. Then the green bricks have been mould, dried for 2 days underneath sunlight, baked and physical properties analysed. The analyses of average density, average water absorption, average compressive strength and average flexural strength of the fired clay brick blended with $8 \%$ bamboo leaf ash (BLA) are 1129 $\mathrm{kg} . \mathrm{m}^{-3}, 21.5 \%, 70 \mathrm{~kg} . \mathrm{cm}^{-2}$ and $0.56 \mathrm{~kg} . \mathrm{cm}^{-2}$ respectively. These physical properties have been compared with the control brick purely manufactured from clay. From the results, clay-BLA bricks are perceptibly better than the control brick; those are available in the Eastern region markets.
\end{abstract}

Keywords: Bamboo Leaf Ash, Clay Bricks, Compressive Strength, Flexural Strength, Water Absorption, Silica Oxide $\left(\mathrm{SiO}_{2}\right)$, Aluminum Oxide $\left(\mathrm{Al}_{2} \mathrm{O}_{3}\right)$ and Ferrous Oxide $\left(\mathrm{Fe}_{2} \mathrm{O}_{3}\right)$

\section{Introduction}

A clay brick is one of the prime building materials made of clay and consumed in an oven [1-3]. Still, this clay brick is made locally and has been accentuated everywhere throughout the world in view of their simple accessibility and minimal effort. Clay brick has been viewed as one of the longest enduring and most grounded constructing material, produced using locally accessible sources, utilized all through history. Common building clay brick is made of a blend of clay, which is subjected to a scope of procedures; vary as indicated by the type of the material, the strategy for make and the character of the finished item [1-3]. The final result is framed in molds to the coveted shape, dried and consume. Consumed clay brick is normally more grounded than sun-dried clay brick [2], particularly on the off chance that it is made of mud or clayey material. The primary impediment is the natural effect engaged with the assembling procedure of clay brick. To beat this disadvantage a test has been made to raise the general productivity of clay brick by including other reasonable materials alongside dirt in the assembling procedure [4-8]. Considering ecological effect 
and the effectiveness, there is a need to locate some elective in order to lessen the effect of the dirt clay brick fabricating process on the earth [9] and in the meantime increment the general execution of the clay brick. This exploration intends to accomplish both the specified changes by utilizing admixtures alongside dirt amid the assembling procedure. Certain admixtures are added to build the bond between the particles and in this manner increment the quality of the clay brick. Such admixtures are either cementitious or pozzolanic materials. Pozzolanic materials incorporate the conventional lime. The current non-customary pozzolanic admixtures are wood fiery remains, sawdust powder and fly cinder [10-19]. The second classification of admixtures comprise of a natural issue, for example, rice husks, sawdust, coal, and so forth., which wear out when the clay brick experience terminating [20-23]. They control the temperature to which the clay brick is let go amid consuming, which is of incomparable significance. The higher the terminating temperature, the higher is the nature of the completed item.

The investigation was expected to make clay brick of clay blended with Bamboo leaf ash (BLA) with different proportions, through the crystallization procedure. The delivered clay brick should meet the required estimations of compressive quality, flexural quality and water retention doled out by the Sri Lankan or British Standard Specifications for stack bearing clay brick. The delivered block was likewise intended to contend with business clay brick, which was made in light of the current situation of the examination, that accessible in the Sri Lankan advertise.

\section{Experimental Methodology}

\subsection{Materials}

(a). Brick Clay

The clay for this study has been acquired from Verpavettuvan, on the depth of 1 to $1.5 \mathrm{~m}$ beneath the earth surface, which is one of the most popular places for clay brick (located in Batticaloa District, Eastern Province of Sri Lanka) is shown in Figure 1. The oxide syntheses of the clay were examined by X-Ray fluorescence (XRF), utilizing a Philips PW 780 instrument, with an anticathode container of rhodium of $4 \mathrm{KW}$, which affirm that the real oxide syntheses of the clay are silica, alumina, and ferric oxide, are given in Table 1 . The higher silica rate in the clay builds the quality of the clay brick [24].

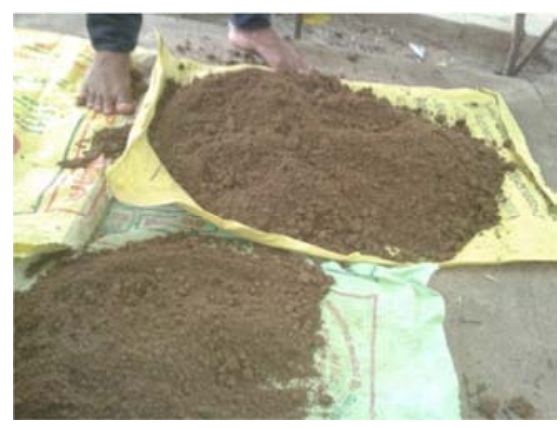

Figure 1. Verpavettuvan brick clay acquired on the depth of 1 to $1.5 \mathrm{~m}$ below the earth surface, which is located in Batticaloa District, Eastern Province of Sri Lanka.

Table 1. The oxide syntheses of Verpavettuvan brick clay.

\begin{tabular}{|c|c|c|c|c|c|c|c|c|c|c|c|}
\hline Oxide syntheses (\%) & $\mathrm{SiO}_{2}$ & $\mathrm{Fe}_{2} \mathrm{O}_{3}$ & $\mathbf{A l}_{2} \mathbf{O}_{3}$ & $\mathrm{CaO}$ & MgO & $\mathrm{SO}_{3}$ & $\mathrm{Na}_{2} \mathrm{O}$ & $\mathbf{K}_{2} \mathbf{O}$ & $\mathrm{TiO}_{2}$ & $\mathbf{P}_{2} \mathbf{O}_{3}$ & LIO \\
\hline Present study $[25,26]$ & 63.10 & 9.23 & 10.63 & 5.03 & 0.02 & 0.01 & 1.03 & 0.02 & - & - & 8.23 \\
\hline Badr El-Din et al. [19] & 65.20 & 7.36 & 15.26 & 1.01 & 0.83 & 0.08 & 3.12 & 0.62 & 1.92 & 0.15 & 6.01 \\
\hline
\end{tabular}

(b). BAMBOO LEAF ASH (BLA)

The bamboo leaves have been gathered in the Agricultural ranch, Eastern University, Sri Lanka is appeared in Figure 2. The leaves have been cleaned and dried in the daylight of temperature around $40^{\circ} \mathrm{C}$, consumed in an open climate. At that point, the coal has been warmed in a suppress heater at $600^{\circ} \mathrm{C}$ for 2 hours to acquire the BLA. After that, the coal has been permitted to cool and afterward sieved through a strainer size of $200 \mu \mathrm{m}$ to acquire the ash. The ash has been protected in fixed glass containers to avert dampness ingestion and other pollution. Be that as it may, the primary point of the examination has been to scatter the information of significant worth expansion among the brick creation group and presenting the green condition by using the regular agro squander materials. The oxide syntheses of the BLA have been researched by X-Ray fluorescence (XRF), utilizing a Philips PW 780 instrument, with an anticathode container of rhodium of $4 \mathrm{KW}$ and the outcomes classified in Table 2 that contrasted and the past examinations. These mixes are known to have concrete properties that would be received by the brick to upgrade the authoritative.
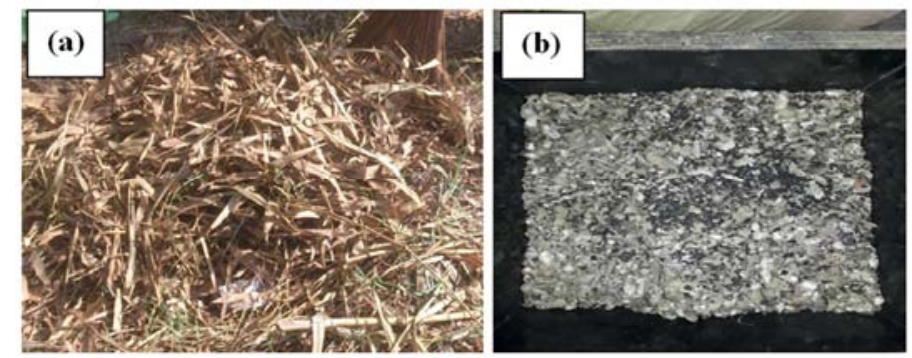

Figure 2. (a) Bamboo leaves have been gathered in the Agricultural farm, Eastern University, Sri Lanka. (b) Bamboo leaf ash (BLA) used to investigate the oxide syntheses. 
Table 2. The oxide syntheses of Bamboo Leaf Ash (BLA).

\begin{tabular}{|c|c|c|c|c|c|}
\hline Oxide compositions (wt\%) & Present study & $\begin{array}{l}\text { N. F. Utodio et. al. } \\
\text { [27] }\end{array}$ & $\begin{array}{l}\text { K. J. Temitope et. al. } \\
\text { [28] }\end{array}$ & $\begin{array}{l}\text { E. Villar-Cociña } \\
\text { et. al. [29] }\end{array}$ & $\begin{array}{l}\text { I. O. Olofintuyi et. al. } \\
\text { [30] }\end{array}$ \\
\hline $\mathrm{SiO}_{2}$ & 81.01 & 51.99 & 72.97 & 80.4 & 75.69 \\
\hline $\mathrm{Al}_{2} \mathrm{O}_{3}$ & 2.14 & 10.10 & 2.85 & 1.22 & 3.64 \\
\hline $\mathrm{Fe}_{2} \mathrm{O}_{3}$ & 8.34 & 6.85 & 2.31 & 0.71 & 5.06 \\
\hline $\mathrm{CaO}$ & 3.02 & 12.51 & 4.98 & 5.06 & 6.74 \\
\hline $\mathrm{MgO}$ & 0.56 & 2.10 & 1.23 & 0.99 & 3.74 \\
\hline $\mathrm{Na}_{2} \mathrm{O}$ & 1.05 & 1.69 & 0.00 & 0.08 & - \\
\hline $\mathrm{K}_{2} \mathrm{O}$ & 1.32 & 3.39 & 6.07 & 1.33 & 0.35 \\
\hline $\mathrm{TiO}_{2}$ & 0.52 & 0.20 & 0.41 & - & 2.05 \\
\hline $\mathrm{SO}_{3}$ & 1.01 & 2.74 & 0.55 & 1.07 & - \\
\hline $\mathrm{Mn}_{2} \mathrm{O}_{3}$ & - & - & 0.41 & - & - \\
\hline $\mathrm{Cr}_{2} \mathrm{O}_{3}$ & - & - & 0.05 & - & - \\
\hline $\mathrm{P}_{2} \mathrm{O}_{5}$ & - & - & 2.37 & 0.56 & - \\
\hline Free Lime & - & - & 0.05 & - & - \\
\hline $\mathrm{MnO}$ & - & - & - & 0.20 & - \\
\hline $\mathrm{ZnO}$ & - & - & - & 0.07 & - \\
\hline LOI & 1.02 & 0.09 & 4.20 & 8.04 & 2.71 \\
\hline
\end{tabular}

\subsection{Sample Preparation [25, 26]}

Six types of brick have been manufactured by applying conventional method, which consists of BLA ratio $0,2,4,6$, 8 and $10 \%$ of the total weight of mixture as shown in Figure 3 (a) to (h). Each type holds seven bricks of dimension 185 $\mathrm{mm} \times 85 \mathrm{~mm} \times 65 \mathrm{~mm}$ as given in Table 3. Traditional brick manufacturing method has been employed to mix the raw materials. Initially, the clay soil has been well prepared with the addition of sufficient water of water/clay ratio 0.7 to 0.8 into a suitable correct plasticity and good workability. Then the BLA has been mixed with the pre-prepared clay manually until proper mixing reached. After that, the raw materials were placed in the mould to dig up the green bricks. These green clay bricks have been protected by sawdust to avoid engaging with other newly prepared clay bricks. These green clay bricks have been subjected to direct air dry under the sunlight of temperature around $35^{\circ} \mathrm{C}$ for one week. Then the green clay bricks have been burned in a brick kiln of burning temperature range $600^{\circ} \mathrm{C}$ to $850^{\circ} \mathrm{C}$, which is the industrial scale manufacturing process of fired clay bricks in the Eastern region of Sri Lanka. The burning process has been continuously carried out for two days and kept about one week. The properties of the fired bricks have been analyzed.

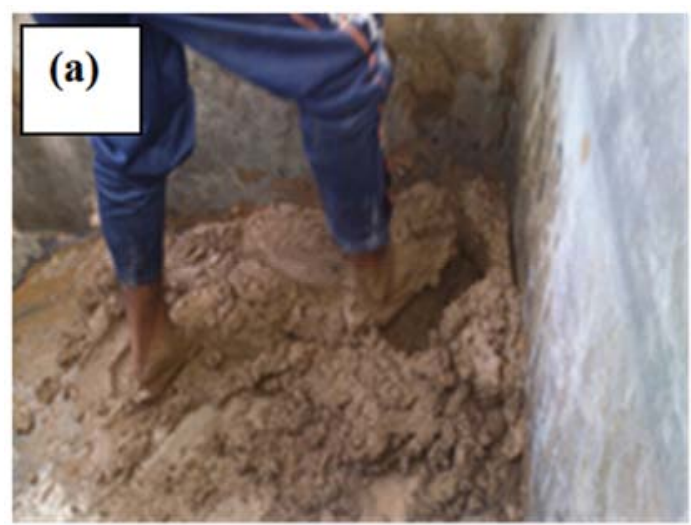

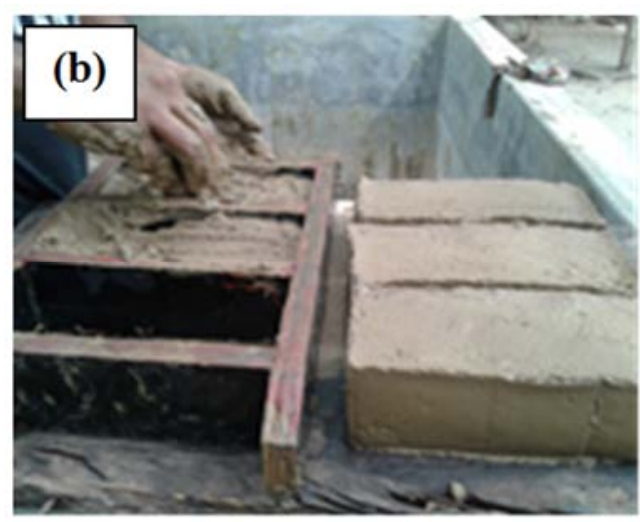
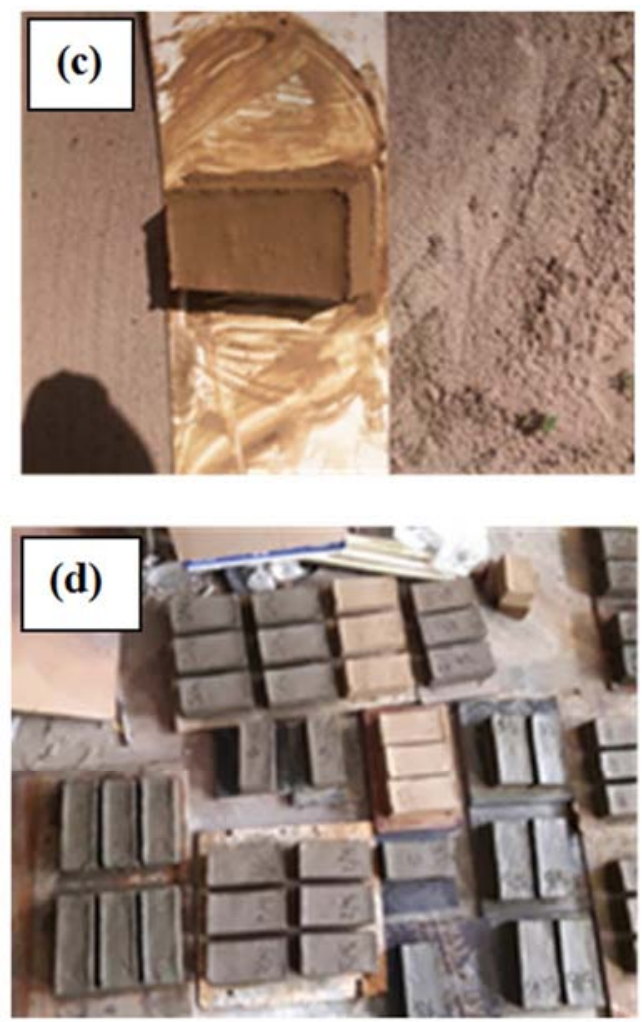

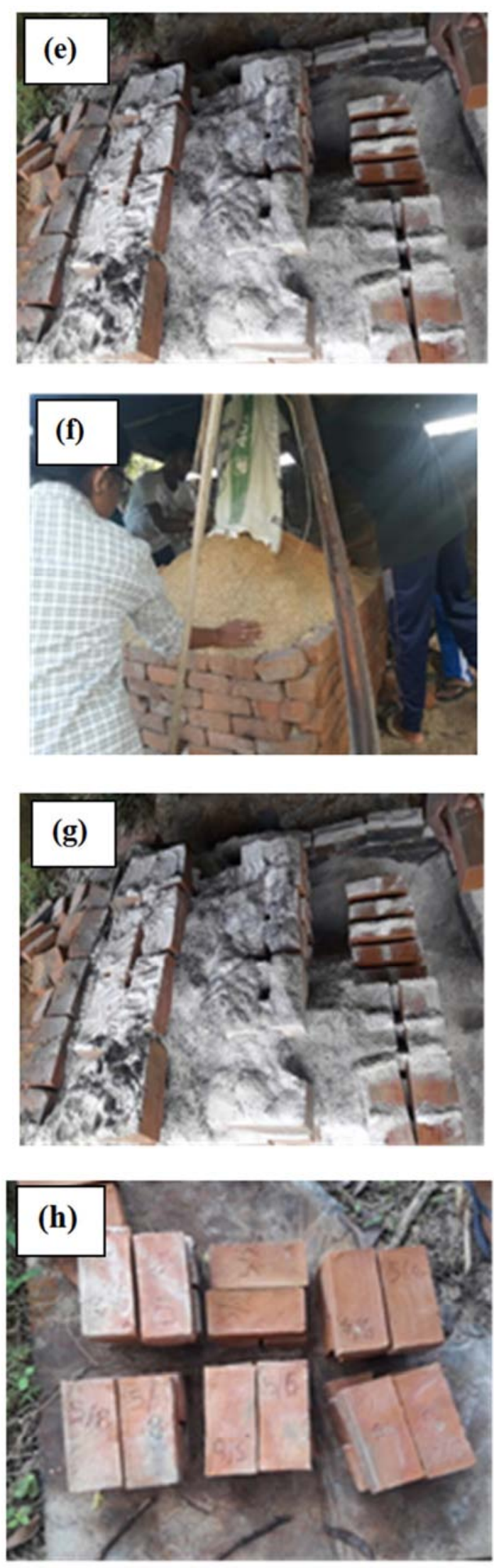

Figure 3. (a). Mixing clay and bamboo leaf ash, (b). Molding the mixture, (c). Green brick of dimension $185 \mathrm{~mm} \times 85 \mathrm{~mm} \times 65 \mathrm{~mm}$, (d). Types of green bricks, (e), Conventional brick kiln, (f). Burning final stage and (g) burnt red clay-BLA bricks.
Table 3. Different mixing proportions of Bamboo leaf ash.

\begin{tabular}{lll}
\hline Brick Type & Brick Clay (wt. \%) & Bamboo Leaf Ash (BLA) (wt. \%) \\
\hline A & 100 & 00 \\
B & 98 & 02 \\
C & 96 & 04 \\
D & 94 & 06 \\
E & 92 & 08 \\
F & 90 & 10 \\
\hline
\end{tabular}

\subsection{Experimental Investigations of Fired Clay Bricks}

Four main investigations have been performed in this study namely; density, compressive strength, flexural strength and water absorption. These investigations have been performed according to Sri Lankan, British and Indonesian Standard Specifications, SL, BS and SNI respectively which are similar to ASTM C67-05 [31].

\subsubsection{Partial Size Investigation}

Particle size determination can be done by different size of sieves, but this investigation has not done because the aim of the study was to disseminate the facts to the local markets and pick up the self-employment society.

\subsubsection{Density (P) Investigation}

Density is defined as the ratio between the dry mass, $m$, and the volume, $V$, of the clay brick, quantifying the quantity of clay found in the volume. It is evident from the definition; higher value is the denser brick and evidently enhanced its mechanical and durability properties. Literature shows that the typical value of the apparent density of the normal fired clay brick range from 1200 to $2200 \mathrm{~kg} . \mathrm{m}^{-3}$ [32].

$$
\rho=m / V
$$

\subsubsection{Water Absorption (WA) Investigation}

Water absorption investigation has been carried out to test the water absorption property of the fired clay bricks. Three bricks from each type have been analyzed. Initially, the bricks have been kept under sundry of the temperature of $35^{\circ} \mathrm{C}$ to $40{ }^{\circ} \mathrm{C}$ for 7 days and the dry weight of the bricks have been measured. These bricks have been immersed in the water for 1 day and the wet weight of each brick has been measured. Water absorption is presented as a percentage using the below equation, and the average has been calculated for each type.

$$
W A=\left[\left(M_{2}-M_{1}\right) / M_{1}\right] \times 100 \%
$$

Where $M_{1}-$ the mass of the dry brick and $M_{2}-$ the mass of the wet brick after 1 day.

\subsubsection{Compressive Strength (CS) Investigation}

Compressive strength investigation has been done using Universal Testing Machine available in the Department of Physics, Eastern University, Sri Lanka. Initially, the brick surface was smoothening to get the parallel surface to form a good surface contact between the brick and the two pressing jaws in the machine. The brick setup for measurement is shown in Figure 4. The compressive strength of bricks has been measured with the help of a pressure gauge of 
sensitivity $2 \mathrm{~kg} \cdot \mathrm{cm}^{-2}$ attached to the Universal Testing Machine. The maximum force applied to just break the brick (or force failure), $F_{\mathrm{m}}\left(\mathrm{kg} \cdot \mathrm{cm}^{-2}\right)$, width, $d(\mathrm{~mm})$, and length, $l$ $(\mathrm{mm})$, of the brick has been recorded. Three blocks from each type have been measured and the average compressive strength has been determined and compared with the standards.

$$
C S=F_{m} / d \times l
$$
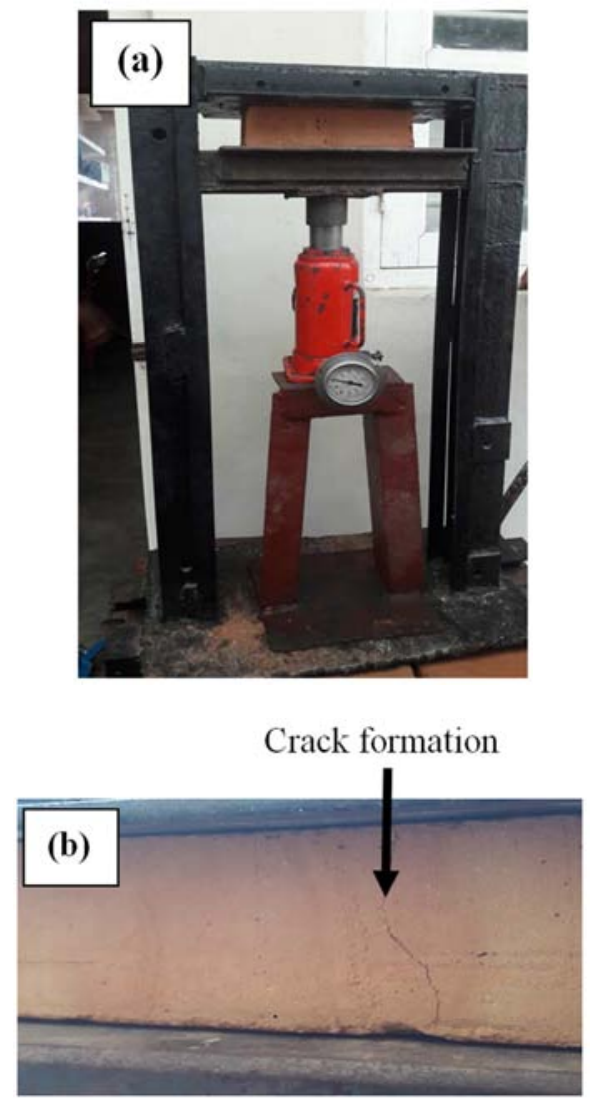

Figure 4. (a). The brick has been ready to measure the point of force failure and (b) Formation of crack indicates the force failure point.

\subsubsection{Flexural Strength (FS) Investigation}

Three-point bending investigation has been done using Universal Testing Machine available in the Department of Physics, Eastern University, Sri Lanka to determine the flexural strength of the brick. Before the measurement, the brick surface has been smoothening to get the parallel surface to form a uniform contact between the brick and the three wedges in the machine. The brick setup for measurement is shown in Figure 5. The flexural strength of bricks has been measured with the aid of a pressure of sensitivity $2 \mathrm{~kg} . \mathrm{cm}^{-2}$ attached to the Universal Testing Machine. The applied force failed, $F\left(\mathrm{~kg} . \mathrm{cm}^{-2}\right)$, span length, $L(\mathrm{~mm})$, width, $w(\mathrm{~mm})$, height, $h(\mathrm{~mm})$ and the distance between the line of fracture and the nearest support, $a(\mathrm{~mm})$ have been recorded to determine the flexural strength $(F S)$.

$$
F S=F \times L / w h^{2}=3 F a / 2 w h^{2}
$$

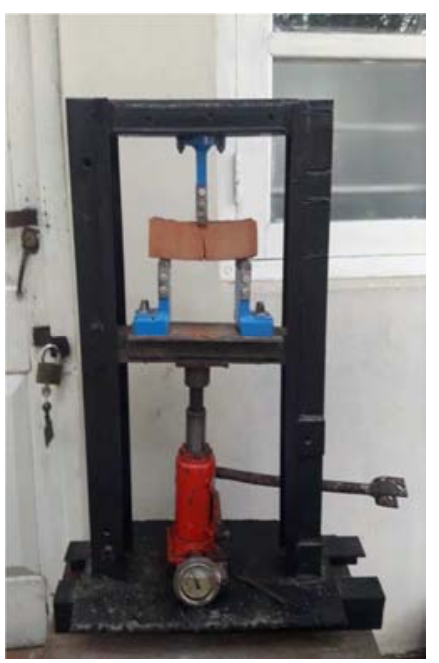

Figure 5. The brick has been ready to measure the point of force failure and the formation of crack indicates the force failure point.

\section{Results and Discussion}

\subsection{Average Density of Fired Clay Brick}

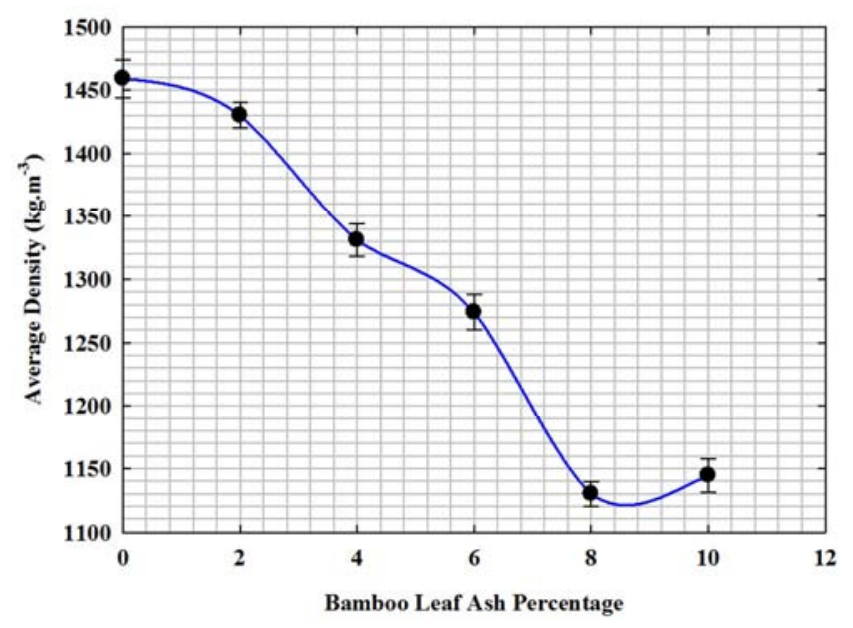

Figure 6. The average density of the fired clay brick as a function of $B L A \%$.

As shown in Figure 6, the average density of the of the fired clay brick sharply decreases with increase BLA percentage up to $8 \%$ of BLA. The minimum average density of $1129 \mathrm{~kg} \cdot \mathrm{m}^{-3}$ is observed for $8 \%$ BLA followed that it shows an increasing behavior. The decreasing behavior could be ascribed to the coating of the clay by the BLA that result to large particles with larger voids and less density [16] or the baking temperature [32]. The researcher [32] reveal that density increases with increasing temperature to the certain limit. According to his [32] statement, density of the clay brick increase from $1800 \mathrm{~kg} \cdot \mathrm{m}^{-3}$ to $2200 \mathrm{~kg} \cdot \mathrm{m}^{-3}$ while increasing baking temperature from $900^{\circ} \mathrm{C}$ to $1100^{\circ} \mathrm{C}$ respectively, which is decreasing form from $2200 \mathrm{~kg} . \mathrm{m}^{-3}$ to $2000 \mathrm{~kg} . \mathrm{m}^{-3}$ while increasing the baking temperature from $1100^{\circ} \mathrm{C}$ to $1200^{\circ} \mathrm{C}$. The effect could depends on the type of the chemical and physical behavior of the clay material.

Not only that this effect is unlike related to normal clay brick due to the mixing of BLA. The formation of the pores 
could be ascribed to the presence of unstable organic compounds in the BLA that burnt off during the firing process. However, the reduction in density is a useful outcome that revealed the potential use of the fired clay bricks as light-weight building materials. Low weight or density has immeasurable advantages such as diminish structural weight, easier management; low costs with transport and environmental friendly. Not only have that in production side more number of bricks can be manufactured per ton of natural agro wasted materials. These bricks can be replaced for standard bricks in most applications, except when bricks of superior strength are required and depends on architectural needs.

As per BS 3921:1982, the minimum density of the normal fired clay brick is 1300 to $2200 \mathrm{~kg} \cdot \mathrm{m}^{-3}[17,33]$. Therefore, the $8 \%$ BLA mixed fired clay brick is most suitable for construction.

\subsection{Water Absorption of Fired Clay Brick}

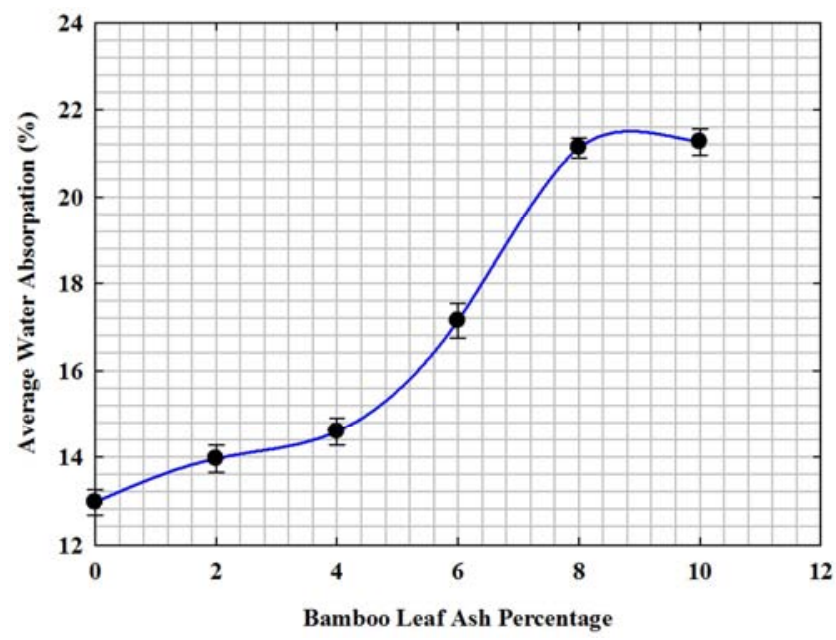

Figure 7. The average water absorption of the fired clay brick as a function of $B L A \%$.

Water absorption is one of the significant property used to determine the quality of the fired clay brick. Figure 7 portrays the average water absorption of the fired clay brick as a function of $\mathrm{BLA} \%$. The average water absorption increases sharply with increasing the BLA\%. It shows a maximum absorption $\approx 21.5 \%$ for $8 \% \mathrm{BLA}$, followed that it decreases. This behaviour shows that the BLA plays a major responsibility in clay-BLA mixture. From the results, the bricks $0 \leq \mathrm{BLA} \%<8$, convince the standard value of $20 \%$ as per the Indonesian Standard SNI 15-2094-2000 [14] and all the bricks except 8 and $10 \%$, convince the standard value of $12 \%$ as per the British Standard BS 5628: Part 1:2005 [15] which lie within the standard values.

The increasing behaviour with increase BLA up to $8 \%$ could be ascribed to comprehensive consumption of calcium hydroxide, $\mathrm{Ca}(\mathrm{OH})$, released through cement hydration by the pozzolanic reaction of the silica in BLA and thereby filling up the pores in the fired clay brick that led to decrease in the amount of water absorption by the brick; and beyond
$8 \%$ BLA content the excess $\mathrm{Ca}(\mathrm{OH})$ which is not consumed by the pozzolanic reaction constitutes weak spots in the brick for water penetration, hence the higher percentage of water absorption. This effect depends on the baking temperatures which ensure the completion of the crystallization process and closes the open pores in the sinter, as well as the effect of the soft nature of the BLA particles, which severely decreases the open pores and significantly reduces the water absorption.

\subsection{Compressive Strength of Fired Clay Brick}

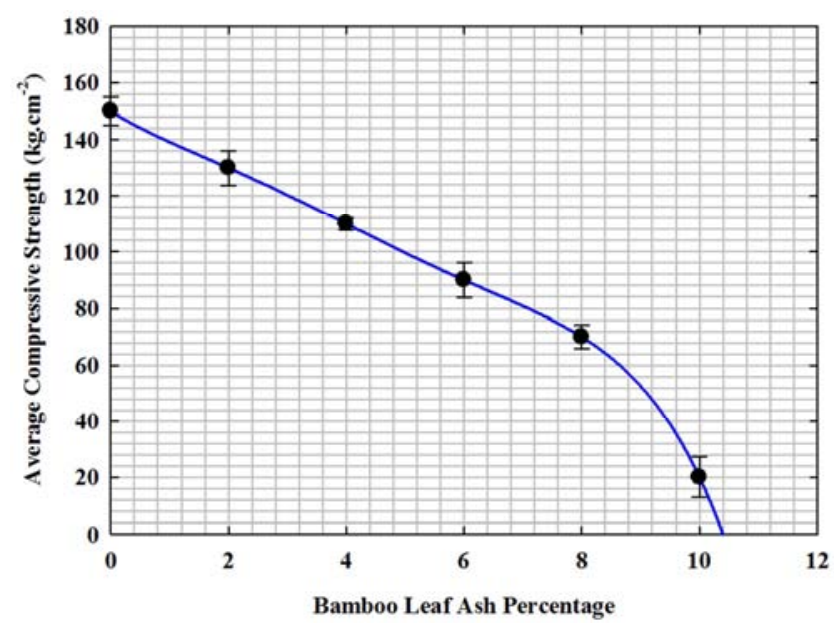

Figure 8. The average compressive strength of the fired clay brick as a function of $B L A \%$.

Compressive strength determines the potential for application of the bricks. Compressive strength is usually affected by the porosity, pore size, and type of crystallization. It is usually defined as the failure stress measured normal to the bed face of the brick. The compressive strength analysis results are shown in Figure 8. The compressive strength of the $0 \%$ BLA clay brick is $150 \mathrm{~kg} \cdot \mathrm{cm}^{-2}$ and the BLA above $0 \%$ clay brick ranged between 130 and $20 \mathrm{~kg}^{-\mathrm{cm}^{-2}}$. The compressive strength decreases smoothly up to $8 \%$ (70 $\mathrm{kg} . \mathrm{cm}^{-2}$ ) and shows a sharp drop. The effect may be due to the higher percentage of pores situated in the fired brick or the week chemical reaction between the materials.

This effect could depend on the baking temperature which ensures the completion of the crystallization process, closes the open pores in the sinter, and, consequently, increases the compressive strength of the crystalline alumina-silicate brick. Recrystallization after de-hydroxylation of water molecules, hence other parameters affects the process of dehydroxylation may cause strength reduction with increases BLA. The de-hydroxylation temperature increases with the increase of water pressure. While the effect of the flabby nature of the BLA particles, which severely increases the open pores in the sinter on decreasing compressive strength is much significant than that of reducing silica content. As a result, increasing BLA ratio generally decreases the open pores in the clay-BLA sinter and, consequently, increases the compressive strength. The plasticity variation indicates that 
the water content increase with increases BLA. Hence these factors may be a root for the reduction of strength when BLA increases. However, 8\% BLA is the maximum optimal dosage and a suitable agent to stabilize the strength of the brick clay which lies within limit recommended by the building authorities.

\subsection{Flexural Strength of Fired Clay Brick}

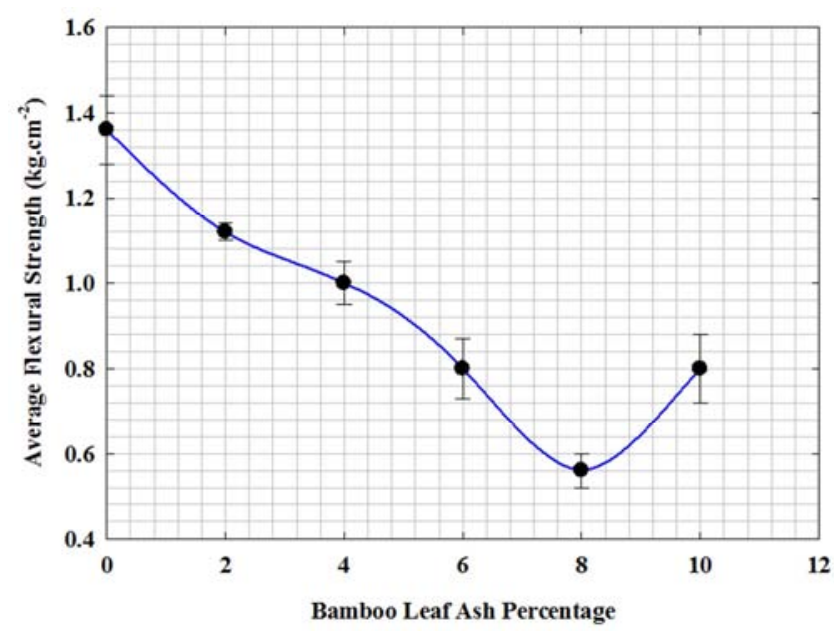

Figure 9. The average flexural strength of the fired clay brick as a function of $B L A \%$.

From Figure 9, it can be clearly seen that the flexural strength decreases smoothly with increases BLA\%. Maximum strength of $1.36 \mathrm{~kg} . \mathrm{cm}^{-2}$ is obtained for $0 \%$ BLA, which is higher than the conventional brick $2.89 \mathrm{MN} . \mathrm{m}^{-2}$ and minimum strength of $0.56 \mathrm{~kg} \cdot \mathrm{cm}^{-2}$ is obtained for $8 \%$ BLA.

\section{Conclusions}

From various physical properties studies performed by doping different percentage of BLA, it could be concluded that partial replacement of BLA improves the physical properties of the fired clay bricks within the limit of experimental error.

The results obtained from this analysis revealed that replacement of $8 \%$ BLA provides optimum values in the compressive strength and the physical properties are given as follows: The average density $1129 \mathrm{~kg} \cdot \mathrm{m}^{-3}$ was recorded and satisfy the requirements as per BS 3921: British standard specifications for brick clay which stated the minimum density of $2000 \mathrm{~kg} \cdot \mathrm{m}^{-3}$. According to the results, all the brick, satisfy recommended water absorption value of $20 \%$ as per the Indonesian Standard SNI 15-2094-2000 and $12 \%$ as per the British Standard BS 5628: Part 1:2005 which lie within the standard values. The maximum compressive and flexural strength $70 \mathrm{~kg} . \mathrm{cm}^{-2}$ and 0.56 $\mathrm{kg} . \mathrm{cm}^{-2}$ were recorded respectively. According to the BS 3921 , the compressive strength of the fired clay brick should be greater than $50.98 \mathrm{~kg} . \mathrm{cm}^{-2}$. For a single story building minimum, compressive strength should be within the range 10 to $50.98 \mathrm{~kg} . \mathrm{cm}^{-2}$ and recommended by the building authorities.
The newly born clay bricks are not suite for high strength external construction; because their low strength and the wet environments will be affect the structural integrity. However, the bricks reduce the overall weight of the building due to low density and weight. Thus, the bricks can be used for interior wall partitions and decorations.

This new clay bricks can be manufactured on site itself, low cost, semi labour skills, and local economy will flourish. Not only has that by introducing the use of locally available natural agro waste materials directed to an ecological structure.

Therefore, $8 \%$ BLA could be suggested for use in enlightening the physical properties of the fired clay bricks than the conventional fired clay brick.

\section{Acknowledgements}

The authors express their gratitude to the Department of Physics, Faculty of Science, Eastern University, Sri Lanka for their support to accomplish this work.

\section{References}

[1] Edward A and Robert H. Fundamental of residential construction (3rd edition), 672 pages. John Wiley \& Sons, San Francisco, USA, 2011.

[2] Roy C and Roger G. Construction Technology (4thedition), 634 pages. Prentice Hill, New Jersey, USA, 2000.

[3] Jeorge J. Venta and Eng P. "Life cycle analysis of brick and mortar products", the ATHENATM Sustainable Material Institute, Canada, Ottawa, 1998.

[4] Rahman M. A. "Properties of clay-sand-rice husk ash mixed bricks", International Journal of Cement Composite Lightweight Concrete, Vol. 9. Pp. 105-108, 1987.

[5] Faria K. C. P., Gurgel R. F. and Holanda J. N. F. "Recycling of sugarcane bagasse ash waste in the production of clay bricks", Environmental Management, Vol. 101. Pp. 7-12, 2012.

[6] Raut S. P., Ralegaonkar R. V. and Mandavgane S. A. "Development of sustainable construction material using industrial and agricultural solid waste: A review of wastecreate bricks", Construction and Building Material, Vol. 25. Pp. 4037-4043, 2011.

[7] Kae Long Lin. "Feasibility study of using brick made from municipal solid waste incinerator fly ash slag", Journal of Hazardous Materials, Vol. 137. Pp. 1810-1816, 2006.

[8] Alaa A. Shakir and Ali A Mohammed. "Manufacturing of Bricks in the Past, in the Present and in the Future: A state of the Art Review", International Journal of Advances in Applied Sciences, Vol. 2. No. 3. Pp. 145-156, 2013.

[9] Dondi M, Marsigli M and Fabbri B. "Recycling of industrial and urban wastes in brick production", Tile Brick International, Vol. 13. Pp. 218-225, 1997.

[10] Kute S, Deodhar S. "Effect of fly ash and temperature on properties of burnt clay bricks", Journal of Institute of Engineers, Vol. 84. Pp. 82-85, 2003. 
[11] Ducman V and Kopar T. "The influence of different waste additions to clay-product mixtures", Material Technology, Vol. 416. Pp. 289-293, 2007.

[12] Hauck D, Ruppik M and Hornschemeyer S. "Influence of the raw material composition on the strength and thermal conductivity of vertically perforated clay bricks and blocks", $Z i$-Annual, annual for the brick and tile, structural ceramics and clay pipe industries, Vol. 4. Pp. 54-80, 1998.

[13] Valenti G. L., Cioffi R., Santoro L and Ranchetti S. "Influence of chemical and physical properties of Italian fly ash on reactivity towards lime, phosphogypsum and water", Cement and Concrete Resources, Vol. 18. Pp. 91-102, 1988.

[14] Bhanumathidas N and Kalidas N. "New trends in bricks and blocks - the role of FaL-G", Indian Concrete Journal, Vol. 66. Pp. 389-392, 1992.

[15] Singh L. P. "Investigation of physical properties of bricks utilizing fly ash, lime and gypsum", Master thesis, Kanpur University, Kanpur, India, 1994.

[16] Kumar S. "Fly ash-lime-phosphogypsum cementitious binder- a new trend in bricks", Material and Structure, Vol. 33. Pp. 59-64, 2000.

[17] Quintilio Piattoni, Enrico Quagliarini, Stefano Lenci. "Experimental analysis and modeling of the mechanical behavior of earthen bricks", Construction Building Material, Vol. 25. Pp. 2067-2075, 2011.

[18] Kidsarin pimraksa, Mathias welhlem, Michael Kochberger and Werner Wruss." A new approach to the production of bricks made with 100\% Fly ash", 2001 International Ash Utilization Symposium. Center of Applied energy Research, University of Kentucky, Lexington, United Kingdom, 2001.

[19] Badr El-Din Ezzat Hegazy, Hanan Ahmed Fouad and Ahmed Mohammed Hassanain. "Incorporation of water sludge, silica fume, and rice husk ash in brick making", Advances in Environmental Research, Vol. 1. Pp. 83-96, 2012.

[20] Michele Dondi, Guia Guarini, Mariarosa Raimondo, Chiara Zanelli, Daniele Dalle Fabbriche and Antonio Agostini."Recycling the insoluble residue from titania slag dissolution (tionite) in clay bricks", Ceramic International, Vol. 36. Pp. 2461-2467, 2010.

[21] Ismail Demir. "Effect of organic residues addition on the technological properties of clay bricks", Waste Management Research, Vol. 28. Pp. 622-627, 2008.

[22] Dondi M., Guarini G., Raimondo M. and Zanelli C. "Recycling PC and TV waste glass in clay bricks and roof tiles", Waste Management, Vol. 29. Pp. 1945-1951, 2009.
[23] Kae Long Lin. "Feasibility study of using brick made from municipal solid waste incinerator fly ash slag", Journal of Hazardous Materials, Vol. 137. Pp. 1810-1816, 2006.

[24] De Silva P. and Crenstil K. S. 'The Effect of $\mathrm{Al} 2 \mathrm{O} 3$ and $\mathrm{SiO} 2$ On Setting and Hardening of Na2O-Al2O3-SiO2- $\mathrm{H} 2 \mathrm{O}$ Geopolymer Systems', J. Aust. Ceram. Soc. Vol. 44. No. 1. Pp. 39-46, 2008.

[25] Fernando P. R. "Experimental Investigation of the Effect of Fired Clay Brick on Partial Replacement of Rice Husk Ash (RHA) with Brick Clay", Advances in Recycling \& Waste Management, USA, Vol. 2(1). Pp. 120, 2017.

[26] Fernando P. R. "Mechanical and Physical Properties of Fired Clay Brick Partial Doped with Coconut Shell Ash", American Journal of Energy and Natural Resources, Vol. 6(5). Pp. 5863, 2017.

[27] Utodio N. F., Ekandem E. S., Egege C. C., Ocholi M., Atakpu O. D. and Nwaigwe D. N, Investigation of the Effect of Bamboo Leaf Ash Blended Cement on Engineering Properties of Lateritic Blocks, Journal of Sustainable Development Studies, Vol. 8(1). Pp. 193-208, 2015.

[28] Kolawole John Temitopeab, Olusola Kolapo Olubunmi and Ata Olugbenga, Strength of Bamboo Leaf Ash and Pulverized Burnt Clay Waste Blended Cement Concrete, IOSR Journal of Mechanical and Civil Engineering (IOSR-JMCE), Vol. 12(6), Pp. 36-42, 2015.

[29] Ernesto Villar-Cociña, Eduardo Valencia Morales, Sergio F. Santos, Holmer Savastano Jr. and Moisés Frías, Pozzolanic behavior of bamboo leaf ash: Characterization and determination of the kinetic parameters, Elsevier, Cement \& Concrete Composites Vol. 33, Pp. 68-73, 2015.

[30] Olofintuyi I. O., Oluborode K. D and Adegbite I, Structural value of bamboo leaf ash as a pozzolanic material in a blended portland cement, international journal of engineering sciences \& research technology, vol. 4(9), pp. 171-177, 2015.

[31] ASTM C67-05, Standard Test Methods for Sampling and Testing Brick and Structural Clay Tile, ASTM International, West Conshohocken, PA, 2005, www.astm.org.

[32] Kiyohiko I., Hyung-Sun K., Koichi K and Atsuchi, H. Influence of firing temperature on frost resistance of roofing tiles. Journal of the European ceramic Society, Vol. 24(14), Pp. 3671-3677, 2004.

[33] Australian / New Zealand Standards AS/NZS 4455.1:2008. Masonry units, pavers, flags and segmental retaining wall units-Masonry units, 2008. 